\title{
SODOBNI POGLED NA PREKOMEJNO SODELOVANJE NA OBMOČJU ITALJANSKO-AVSTRIJSKO-SLOVENSKE TROMEJE (1)
}

\author{
Anton Gosar*
}

Izvleček

UDK 911.3:341.222(497.12:436:450)

Proučevanje območij ob italjansko-avstrijsko-slovenski meji ima dolgoletno tradicijo. Načrte za poručevanje možnosti za komplementaren razvoj pokrajine ob Tromeji(1) so pred leti ustrezno zastavili geografi tržaške, videmske, celovške in ljubljanske univerze. V tem članku navajamo izsledke raziskave, ki obravnava etničnost in nanjo navezano vrednotenje kulture sosednjih narodov. Poleg tega analizira znanje italjanskega in nemškega jezika v izbranih naseljih Doline in Zgornjega Posočja.

Ključne besede: prekomejno sodelovanje, komplementaren razvoj, Tromeja - obmejno območje Avstrije, Italije in Slovenije, etnične značilnosti, vrednotenje kulturnih značilnosti, znanje nemščine \& italjanščine, Zgornja Dolina, Zgornje Posočje.

The area wher three-borders of Austria, Italy and Sloveia meet was centuries long a transitional egion between the core areas of the Mediterranean and Alps. The under Austria unified area was divided among three states in 1918. Since than diverse systems in economy and politics have changed the once supportive economies. Tendencies to develop in each of the bordering states such economies which would support each other are becoming a reality. Studies, performed by universities of Ljubljana, Trieste, Udine and Klagenfurt should provide knowledge on the existing socio-geographic structure of the above named border regions.

Key words: Transborder cooperation, language knowledge, the three-border area, Slovenia, Carinthia, FriuliVenetia Giulia

\section{UVOD}

Slovenska geografija je že sredi 60 . let posvetila precej pozornosti vprašanjem meja, manjšinam ob mejah in trgovskim in turističnim prekomejnim tokovom. Bila je med prvimi v Evropi, saj so se podobnih vprašanj takrat lotevali samo še na območju Regio Basiliensis, značilni obmejni pokrajini Francije, Nemčije in Švice. Med številnimi odmevnimi prireditvami, ki smo jih organizirali v želji promovirati naše takratne raziskovalne izsledke sodi nedvomno posvetovanje Turizem in meje, ki je potekalo pod pokroviteljstvom Mednarodnega združenja geografov leta 1978 v Ljubljani in Trstu (Gosar, 1979). Vzporedno $\mathrm{z}$ dozorevanjem predrevolucionarne kritične mase $\mathrm{v}$ osrednji in vzhodni Evropi in zavedanjem geografov o pomembnosti vedenj o funkcioniranju obmejnih regij, so podobne posvete kasneje organizirali na univerzah in raziskovalnih ustanovah tostran in onstran

* Dr. izr. prof., Oddelek za geografijo, Filozofska fakulteta, Univerza v Ljubljani, 61000 Ljubljana, Aškerčeva cesta 2, SLO 
"železne zavese". Organizatorji so upoštevali slovenske izkušnje in jih vgradili v svoja razmišljanja. Vabljeni na te prireditve, smo imeli slovenski geografi na njih praviloma vidno mesto (Gosar, 1984).

Ožje območje Tromeje zajema 740 km2 alpskega gorskega (Julijske/Karnijske Alpe/Karavanke) in dolinskega sveta ob rekah Savi, Zilji in Beli. Sestavljajo ga katasterske občine Rateče, Podkoren, Kranjska gora in Gozd ( $147 \mathrm{~km} 2$ ali $20 \%$ ozemlja) v Sloveniji;občine Tarvisio, Malborghetto-Valbruna in Pontebba ( $425 \mathrm{~km} 2$ ali $57 \%$ ozemlja) v Italiji; ter občini Arnoldstein in Finkenstein (169 km2 ali $23 \%$ ozemlja) v Avstriji. V širšo obravnavo smo vključili Dolino in Zgornje Posočje!

Vsebinsko kulminacijo so raziskave te vrste dosegle, ko so pri terenskem proučevanju pričeli sodelovati strokovnjaki iz obeh strani meje. Eno prvih evropskih institucij tripartitnega, meduniverzitetnega in mednarodnega, terenskega geografskega proučevanja obmejne pokrajine so vzpostavile univerze v Ljubljani, Celovcu, Vidmu in Trstu. Slovenski, avstrijski in italjanski geografi so se dogovorili, da bodo večletno raziskovalno pozornost namenili območju ob stičišču treh meja. Podporo zamisli so v verbalni obliki dale deželne vlade, obmejne občine in delovna skupnost evropskih regij Alpe-Adria. Izsledke uvodnega, dveletnega skupinskega dela so leta 1990 trojezično objavili v reviji Oddelka za geografijo DELA - "Tromeja - Obmejna regija Jugoslavije, Avstrije in Italije" (Pak, 1990). V njej so ovrednotili pokrajinsko podobo ob Tromeji, prvenstveno iz historičnogeografskega vidika. Raziskava se je poslej usmerila v proučevanje prostorskih struktur, ki bi naj v sedanji obliki ali ob ustrezni preobrazbi pripomogle $\mathrm{k}$ skladnejšemu razvoju sosednjih regij treh držav. Izbranevsebine predstavljamo na tem mestu.

\section{POMEMBNEJŠE SESTAVINE IN PROCESI PREOBLIKOVANJA}

V preteklosti slovenski geografi nismo preverjali možnosti za soskladen in usmerjen razvoj območij tostran z območji onstran meje. Najpoprej je bilo nestvarno razmišljati o planiranju komplementarnosti prostorskih struktur na območjih, ki jih je ločevala hermetično zaprta meja. Posebej je to veljalo za obmejne pokrajine, kjer so meje ločevale nadnacionalne družbene, ekonomske ali vojaške sisteme. Ob odprtju meja, predvsem na Zahod, smo bili geografi takoj pripravljeni registrirati spremembe, ki jih je v prostor in med ljudi zanesla politična otoplitev. Na vsklajeno delovanje pri oblikovanju enotne obmejne regije takrat še ni bilo mogoče misliti. V kolikor je do dopolnjevanja $v$ trgovini, storitvah in drugih dejavnostih prišlo, je to potekalo ponavadi anarhično, saj je temeljilo izključno na zasebnem ali družbenem profitu. Zaslužek ob meji je bil možen oziroma je izhajal iz različne pravne regulative oziroma ekonomije dežel, ki so mejile druga na drugo. Osrednje institucije države so ponekod obmejni razvoj podpirale - vsaka v lastno korist.

Območje Tromeje je v obdobju Habsburške monarhije pripadalo notranjeavstrijskim pokrajinam Kranjski, Primorski (Goriški) in Koroški. Italjansko mejo so po I. sv. vojni 
Sodobni pogled na prekomejno...

premaknili na Zahod in poprek čez poprejšnje notranjeavstrijske deželne meje: med obema vojnama je posoški del za obdobje 25 let pripadel Italiji. Meja med Slovenijo in Italijo šele v zadnjih štirih desetletjih razmejuje povodja mediteranskega in panonskega oziroma crnomorskega porečja. Slovensko-avstrijska in avstrijsko-italjanska meja potekata vse od dvajsetih let dalje na Karnijskih Alpah oziroma Karavankah. Meja je najprej ločevala kraljevino Jugoslavijo, fašistično Italijo in republiko Avstrijo oziroma nacistični Reich ter kasneje socialistično Jugoslavijo, nevtralno Avstrijo in članico Severno-atlantske zveze, Italijo. Obenem je bila to politična, pravna in gospodarska ločnica med neuvrščeno Jugoslavijo, članico EFTE Avstrijo in članico EGS Italijo. Omenjena politično-geografska dejstva izpostavljamo, saj strukturne spremembe, ki so jih sem zanesli različni, sicer oddaljeni centri moči, idej in kulture, niso preoblikovali le fizične podobe pokrajine (italjanske kasarne, staroavstrijski prometni sistem, slovensko-jugoslovanski policentrični koncept razmeščanja industrije, ... v Sloveniji), temveč so pustili brazgotine tudi v ljudeh. Posredno vplivajo na videnja bodočega razvoja.

Bistvene spremembe so torej zajele kulturno-pokrajino na območju Tromeje v 20. stoletju. V vsaki od treh regij se je nacionalni karakter države kateremu je območje pripadlo okrepil. Migracijski in asimilizacijski procesi so preoblikovali prebivalstveno strukturo; vsedržavni razvojni načrti so bili večidel naravnani tako, da so podpirali nacionalno ekonomijo! Romanski značaj je povsem prevladal nad nemškim in slovenskim v Kanalski dolini v Italiji (Steinecke, 1991/a), Slovanski se je utrdil v Sloveniji (Gosar, 1991), interesi nemškega prebivalstva v Avstriji so postopoma pridobivali prioriteto na Koroškem (Zupančič, 1993). Posočje, ki je v tem stoletju zamenjalo že štiri lastnike je demografsko in ekonomsko najbolj trpelo (Kunaver, 1989). Terenske raziskave opravljene v poletju 1993, o katerih poročamo v naslednjem poglavju, so pokazale, da kljub dokajšnji etnični homogenosti prebivalstvo ni pretirano patriotsko naravnano: staroselci Kanalske doline se radi identificirajo z Avstrijci, prebivalci Posočja pogosto omenjajo prednosti, ki so jih imeli v času pod Italijo, Slovenci v Dolini povdarjajo svoj regionalni, Gorenjski značaj. Razloge za opisano družbeno-politično klimo gre prednostno iskati $v$ dveh dejavnikih:

- v vsesplošni gospodarski krizi, ki je zajela pokrajino ob Tromeji v vseh treh deželah in za katero domačini krivijo matične države oziroma Center; in

- v prebivalstvenih gibanjih, $v$ katerih prevladujejo migracije, ki spreminjajo etnično, demografsko in poselitveno strukturo.

Stanje, ki smo mu danes priča, je rezultat pol- do tričetrt-stoletnega razvoja pokrajine $v$ okrilju obstoječih držav (z izjemo Slovenije). S potegnitvijo meje po I. sv. vojni je poleg tranzitnega in gorskega značaja območje dobilo še obmejni značaj! Zaradi tega so se prilike napram prejšnjim obdobjem bistveno spremenile. Transportna oziroma tranzitna funkcija se je okrepila, vendar ne izključno $v$ tradicionalno prevladujoči smeri vzhod - zahod (Dunaj - Benetke), temveč tudi v smeri sever - jug. Korensko sedlo je bilo svojčas z več kot 250.000 prehodi oseb na dan v sezoni med najbolj obremenjenimi v Alpah (Gosar, 1979). Po številu osebnega prometa je ta mejni prehod obdobno rkašal dolinskega pri Megvarjih, kjer je imel tovorni promet tradicionalno prednost. $\mathrm{Z}$ odprtjem meja Vzhodne Evrope in $\mathrm{z}$ vojno 
na Balkanu se je obremenitev obeh močno spremenila. Na avtocestnem in cestnem mejnem prehodu Megvarje-Vrata dnevno odpravijo več sto avtobusov ter več desettisoč osebnih vozil, vsaj 165.000 oseb in 55.000 ton blaga (Bufon, 1993).

V skladu z nacionalnimi interesi so v Italiji in Avstriji prometno okrepili predvsem smer, ki povezuje Panonsko nižino z Zahodno Evropo. Ranžirno postajo na Brnici so dokončali sredi osemdesetih let, avtocesto po Ziljski in Kanalski dolini so v celoti izgotovili tudi takrat, "avtoporto" pri Trbižu so odprli že nekaj let prej... Mnogo kasneje, ali pa sploh ne, so se lotili podobnega opremljanja smeri, ki vodijo proti jugu, v Slovenijo. V Italiji smeri v Posočje iso obnavljali. Železniško povezavo s Trbižem so na Slovenskem opustili takoj po vojni, dokončno pa so progo po Dolini demontirali leta 1964. Cestni promet se je čez Korensko sedlo v sedemdesetih letih izrazito povečeval, vendar se je cestna infrastruktura le postopoma in z zamudo izboljševala. Slovenski del Tromeje je, še posebej po otvoritvi Karavanškega predora(Podrožca - Hrušica, 1992) ostal prometno izoliran otok.

Nekatere tradicionalne gospodarske panoge iz primarnega in sekundarnega sektorja dejavnosti so morale odstopiti mesto novim funkcijam povezanim s prometom, turizmom in obmejnim značajem regije. Iz Kanalske doline, kjer pravkar dokončujejo traso superhitre železniške proge, je izginilo poljedeljstvo, le životarijo pa nekdaj cvetoče panoge: živinoreja in gozdarstvo z žagarstvom. Podobno velja za rudarstvo in spremljajočo industrijo. Tradicionalno fužinarstvo se je bilo primorano specializirati ali zapreti vrata. Dobro se prodajajo kvalitetne verige izdelane v obratu Weissenfels v Fužinah (Valussi, 1990), predimenzionirana jeseniška železarna pa životari. Prenehali so s kopanjem svinčeve rude v Rajblju (in s tem prenehali onesnaževati Ziljico in Koritnico), obsežen kompleks industrije predelave svinca, BBU v Podkloštru so zaprli. V javnost so prodrle alarmantne vesti o posledičnem onesnaženju prsti v Ziljski dolini. Gorski kmetijski obrati na Karavankah so demografsko ogroženi, dolinski ob Zilji pa kljub komasacijam, oziroma združitvam parcel, ne morejo pridelati cenene hrane. Industrijski obrati ob sotočju Zilje in Drave so v navezavi na beljaški prometni vozel in les edina novejša in vsaj za zdaj uspešna tovrstna investicija. Mednje sodi tudi obrat begunjskega Elana. V Beljaku se je uveljavila novodobna industrija: sem gre šteti tudi edino tovarno računalniških čipov v Srednji Evropi. Slovenski koncept policentričnega industrijskega razvoja ni zanesel večjih obratov v Zgornje Posočje ali Dolino. Družba je podpirala razvoj turizma. Ta je v Dolini cvetel predvsem na račun tranzitnega prometa in v navezavi na jugoslovanski trg. Na Bovškem se kljub finačnim injekcijam ni mogel pošteno vsidrati. Triglavski narodni park je zato leta 1982 brez pretiranega nasprotovanja zaobjel zaledje Tromeje na slovenski strani.

Turistični razvoj so v navezavi na druge prostočasne dejavnosti oziroma prometne tokove podpirali $v$ vseh treh regijah ob Tromeji. Izpostavljali so prednostno gorsko pokrajino, vključno z njeno pleistocensko preteklostjo, ter obmejni značaj obravnavane regije. Ledeniška jezera Baško, Belo in Rabeljsko, divje vode Soče, Koritnice in Zilje so ob alpskih vršacih in panoramah (Trenta, Planica, Reklanska dolina, ...) in smučiščih na Peči, na Sv. Lušarjih, v Kranjski gori in na Kaninu pomembnejši turistično atraktivni ambienti. 
Sodobni pogled na prekomejno...

Ob njih ima pomembno vlogo tudi gostinska in trgovska infrastruktura, ki je nastala predvsem zaradi tovorjenja, denimo v Podkloštru in Trbižu oziroma na osnovi posebnosti, ki jih je nudilo stičišče treh kultur in držav (Steinecke, 1991/b).

Obdobno so se množile (in kasneje propadale) bencinske črpalke, zdaj na tej zdaj na oni strani meje. V vsem obdobju je cvetela trgovina. Najprej samo preko odprte meje med Italijo in Avstrijo. Pri tem se je okrepila predvsem funkcija Trbiža. V sedemdesetih letih se je tej izmenjavi dobrin in storitev pridružil še Beljak in drugi kraji v Avstriji (Wastl-Walter, Krutner, 1991). Po osamosvojitvi Slovenije se je igralništvo (Kranjska gora) uvrstilo med izrazite pritegovalne dejavnike tega območja. Še prej je na podobno intenzivno preobrazbo prometnih tokov vplivalo odprtje carine prostih trgovin (duty free) na slovenski strani mejnih prehodov. Oboje je na nek način kamen spora med državami in gospodarskimi subjekti tega prostora.

Največji turistični promet ustvarijo ob Baškem jezeru (preko 500.000 nočitev letno) in v Kranjski gori (okrog 300.000), manj pa v Trbižu in Bovcu (pod 200.000). Zaradi številnih počitniških hišic in apartmajev, predvsem na italjanski strani Tromeje (Sella Nevea), pa tudi v Dolini in Zg. Posočju, zgornje število ni realen odsev obiska. Ta je mnogo večji, tudi zaradi dnevnih in konectedenskih obiskov (Gosar, 1992). Širše zaledje Tromeje razpolaga $\mathrm{z}$ dodatnimi turističnimi kapacitetami in atrakcijami. Ne gre namreč pozabiti na kongresno in topliško mesto Beljak, smučišča na Mokrinah, stoleten "kinč nebeški" - Bled in tradicionalno središče novodobnega poletnega turizma $v$ tem območju - Koroško riviero oziroma Vrbsko jezero.

Prekomejnih selitev je bilo v obdobju dolgotrajnega miru malo. Drugače pa je bilo v vojnih in povojnih časih. Po prvi svetovni vojni se je nekaj sto družin preselilo v Avstrijo in Jugoslavijo, pred drugo, 1939 se je okrog 5000 optantov odselilo v nemške dežele. Neposredno po drugi svetovni vojni so se na Koroškem naselili iz Vzhodne Evrope pregnani Nemci. V koroški turistični industriji je na območju Tromeje (Bača, Podklošter) zaposleno samo 175 zdomcev; v Italiji dela le nekaj deset Slovencev v fužinski železarni, pred zaprtjem se jih je nekajkrat več dnevno vozilo na delo v rudnik.

Nasprotno pa so bile notranje migracije izrazito intenzivne! $Z$ izjemo Posočja, kjer je upadanje števila prebivalstva rezultat obeh demografskih dejavnikov: (iz)selitev in (nizkega) naravnega prirastka, in je število prebivalstva $v 30$. letih upadlo za tretjino, je povsod drugod prihajalo do obdobnih valov pri- in odselitev, ki so v končni fazi stabilizirali prebivalstveno sliko in ojačali državotvorni, nacionalni značaj regije. Danes živi na območju Tromeje okrog 27.000 ljudi: $12 \%$ na ozemlju Slovenije - brez Bovškega, 36\% v Italiji in $52 \%$ v Avstriji.

Priselitve vojakov, carinikov in policajev so utrdile položaj italjanske narodnosti v Italiji in večnacionalne, slovanske v Sloveniji; doselitve Podonavskih Nemcev so porušile etnično podobo na Koroškem. V Kanalski dolini je bilo leta 1910 razmerje med Italjani in drugimi 
narodnostmi 14 : 86 v korist slednjih; popis leta 1990 je na istem območju zajel $81 \%$ Italjanov, $10 \%$ Slovencev in $9 \%$ Nemcev. V Sloveniji je po številu in deležu ( 7010 preb., $37 \%$ ) priseljenih občanov, neslovenskih državljanov bivše jugoslovanske federacije, jeseniška občina v vrhu. Sem gre uvrstiti tudi turistično območje slovenskega dela Tromeje. V KS Kranjska gora je, ob popisu 1991, 21\% prebivalstva navedlo narodnost, ki na tem območju ni avtohtona (Gosar, 1993).

Turizem v Avstriji in Sloveniji ter trgovina v Italiji sta pritegnila delavce in njih družine iz zaledja. Okrepili so se predvsem centralni kraji, vasi izkazujejo stagnacijo ali depopulacijo. Mnogim je življenje in delo na državni periferiji breme, ki ga sprejmejo na svoja pleča le zaradi zaslužka oziroma državne prisile. Zaradi tega se mnogi po doseženem cilju ( minilo je obvezno obdobje služenja, dosegli so zastavljen finančni cilj) odselijo nazaj, v notranjost države. Ponavadi ne domov, temveč v tukajšnji regionalni center (n.pr.: Videm, Beljak, ...). Prihaja tudi do prepletanja dnevnih migracij (cariniki, policaji). Beljak izstopa po številu delovnih mest.

\section{PLANIRANJE ZA BODOČNOST}

Pokrajine ob meji so že ob koncu šestdesetih let vsklajevale naravovarstvene, vodnogospodarske in turistično-rekreacijske (planinarjenje) interese preko bilateralnih dogovorov zainteresiranih strani (občine, gostinska podjetja, društva) in načrtovale prihodnji razvoj s sodelovanjem v delovni skupnosti Alpe - Jadran. Skupaj so že v sedemdesetih letih organizirali športne prireditve: denimo skoke treh dežel in tradicionalni smučarski tek od Kranjske gore v Sloveniji preko Fužin v Italiji do Podkloštra v Avstriji.

Navdušenje domačinov, predvsem Slovencev za športne prireditve ter interesi industrije v Sloveniji, trgovine v Furlaniji-Julijski krajini ter turistične industrije na širšem območju Koroške so v obdobju "hladne vojne" (odsotnost športnikov iz "kapitalističnih" držav na olimpijskih igrah v Moskvi ter omejena prisotnost športnikov iz "socialističnih" dežel na olimpijadi v Los Angelesu) ideji o organiziranju večje mednarodne športne prireditve na območju treh dežel dale krila. Čeprav statut Mednarodnega olimpijskega komiteja (IOC) ni predvideval oziroma dovoljeval organizacijo iger $v$ dveh ali večih deželah so se na deželni ravni odločili za večkratno tovrmeje. Nekatere rešitve so se oblikovale kar same od sebe oziroma anarhično. Druge bi bilo potrebno načrtovati in udejaniti ob upoštevanju lokalnih naravnih in družbenih resursov (Podlipnig, 1991).

Dosedanji, bolj ali manj anarhični kooperacijski odnosi so vsaj doslej presegli planirane. Mednje gre konstantno šteti trgovino $\mathrm{z}$ gorivom. Zaradi preusmeritve na avtocesto in nekonkurenčne cene zapirajo črpalke (in gostilne) na koroškem delu Tromeje medtem, ko se naval na iste $\mathrm{v}$ Sloveniji stopnjuje. Censka nesorazmerja so primorala celo vlade $\mathrm{k}$ ukrepanju (cenejši bencin za domačine v Italiji). Sporna za trgovce v obeh sosednjih deželah je bila postavitev carine prostih trgovin, ki so odtegnile trafikam in nekaterim obratom tudi 
Sodobni pogled na prekomejno...

do 3/4 dohodka. Svojčas je slovenski zaslužek potoval v Avstrijo in Italijo. Profiti ustvarjeni v špecerijskih trgovinah v Avstriji in tekstilnih ter galanterijskih v Italiji so dodobra oplemenitili obmejno pokrajino (Wastl-Walter, Krutner, 1991).

Raziskava opravljena poleti leta 1993 med 127. gospodinjstvi je pokazala, da so se tovrstni prekomejni nakupovalni tokovi, vsaj na slovenski strani, umirili. Redno, torej vsaj enkrat na mesec se na območju Tromeje odpravlja po nakupih v tujino le četrtina povprašanih gospodinjstev. Obisk italjanskih trgovin je trikrat bolj privlačen kot obisk avstrijskih. Vzroke gre najbrž iskati v na pomlad devalvirani liri oziroma trdni navezanosti avstrijskega šilinga na nemško marko. Indikativno za sedanji gospodarski položaj je, da preko polovice vprašanih ne vidi potrebe po nakupih $\mathrm{v}$ tujini. Vzroki so: večja izbira doma, nižji življenski štandard kot pred leti in ostarelost oziroma nezaposlenost prebivalstva. Na območju Trente kar tričetrt povprašanih gospodinjstev zagotavlja, da sploh ne hodi (več) v tujino. V Dolini se intenziteta obiskov tujine $\mathrm{z}$ oddaljenostjo od Tromeje zmanjšuje. Avstrija, kateri dajajo načeloma prednost, je postala draga, $v$ Italijo hodijo le iz krajev tik ob meji. Zaradi dvolastništva in

Tab. 1: Tromeja - obiski zamejskih krajev v Italiji in Avstriji

Visits of the neighbouring area in Austria and Italy

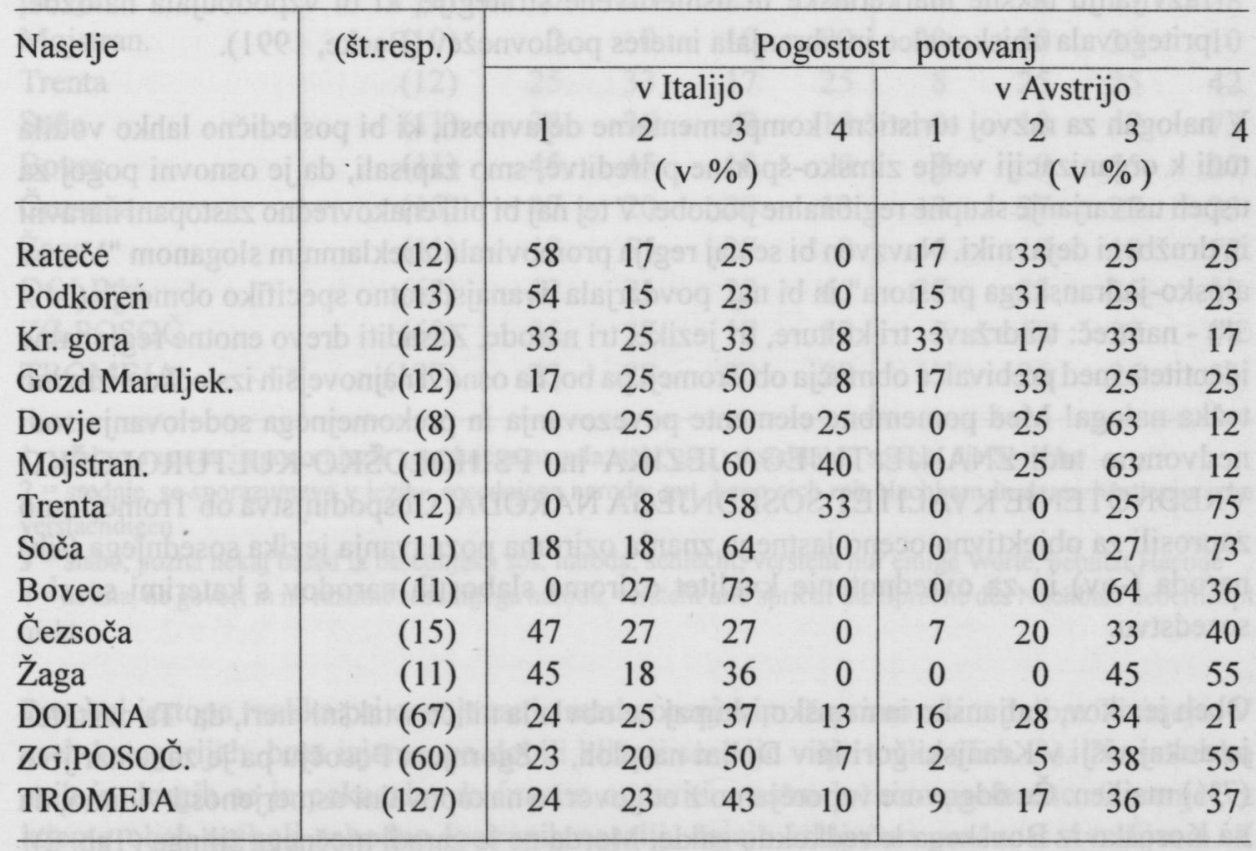

1 = pogosto, vsaj enkrat na mesec / oft, wenigstens $1 \mathrm{x}$ im Monat

$2=$ redno, nekajkrat na leto / regelmaessig, jedoch nicht jeden Monat

3 = poredko, enkrat na leto / sehr selten, ev.einmal im Jahr

4 = skoraj nikoli / fast nie 
slabše trgovske ponudbe doma, tudi po večkratdni navezanosti avstrijskega šilinga na nemško marko. Indikativno za sedanji gospodarski položaj je, da preko polovice vprašanih ne vidi potrebe po nakupih v tujini. Vzroki so: večja izbira doma, nižji življenski štandard kot pred leti in ostarelost oziroma nezaposlenost prebivalstva. Na območju Trente kar tričetrt povprašanih gospodinjstev zagotavlja, da sploh ne hodi (več) v tujino. V Dolini se intenziteta obiskov tujine $\mathrm{z}$ oddaljenostjo od Tromeje zmanjšuje. Avstrija, kateri dajajo načeloma prednost, je postala draga, v Italijo hodijo le iz krajev tik ob meji. Zaradi dvolastništva in slabše trgovske ponudbe doma, tudi po večkrat na teden (Tab. 1).

V smernicah za komplementarni razvoj - panoge razvite na enem območju naj bi podprle panoge v drugi državi - smo geografi pred leti zapisali, da bi morala območja ob Tromeji stremeti k:

* razvijanju tehnične infrastrukture, ki bi bila neodvisna od kontinentalnih tranzitnih poti in bi prednostno služila transnacionalnemu razvoju ob Tromeji;

* bogatenju turističnega in rekreacijskega potenciala ter razvijanju novih, tudi tveganih, vendar sodobnih oblik turistične ponudbe;

* širjenju na tradiciji in znanju temelječe trgovske in drobnogospodarske ponudbe, ki bi naj imela povdarjeno obmejni značaj; in

* razvijanju takšne marketinške in usmeritvene strategije, ki bi vzpodbujala naložbe, pritegovala obiskovalce in ohranjala interes poslovnežev (Backe, 1991).

V nalogah za razvoj turistične komplementarne dejavnosti, ki bi posledično lahko vodila tudi k organizaciji večje zimsko-športne prireditve, smo zapisali, da je osnovni pogoj za uspeh ustvarjanje skupne regionalne podobe. $V$ tej naj bi bili enakovredno zastopani naravni in družbeni dejavniki. Navzven bi se naj regija promovirala z reklamnim sloganom "V srcu alpsko-jadranskega prostora" in bi naj povdarjala dvanajstkratno specifiko območja (" $4 \mathrm{x}$ 3") - namreč: tri države, tri kulture, tri jezike, tri narode. Zasaditi drevo enotne regionalne identitete med prebivalce območja ob Tromeji pa bo, na osnovi najnovejših izsledkov izredno težka naloga! Med pomembne elemente povezovanja in prekomejnega sodelovanja sodi nedvomno tudi ZNANJE TUJEGA JEZIKA in PSIHOLOŠKO-KULTUROLOŠKO VREDNOTENJE KVALITET SOSEDNJEGA NARODA. Gospodinjstva ob Tromeji smo zaprosili za objektivno oceno lastnega znanja oziroma poznavanja jezika sosèdnjega (-ih) naroda (-ov) in za ovrednotenje kvalitet oziroma slabostih narodov $\mathrm{s}$ katerimi so si v sosedstvu.

Obeh jezikov, italjansko in nemško, skupaj ne obvlada nihče v takšni meri, da Ta odstotek je dokaj višji v Kranjski gori in v Dolini nasploh, v Zgornjem Posočju pa je zanemarljivo (7\%) majhen. Če odgovore vzporejamo z odgovori o nakupovalni usmerjenosti vidimo, da na Koroško iz Bovškega le redkokdo zaide. Morda ne le zaradi močnega šilinga (Tab. 2)!

V želji dognati kako gledajo prebivalci iz slovenske strani Tromeje na sosede, smo precej časa posvetili vprašanjem, $v$ katerih so posamezniki ocenjevali karakterne lastnosti Italjanov in Avstrijcev. Večina odgovorov je bila pričakovana. Visoke ocene so dobili Avstrijci za 
Sodobni pogled na prekomejno...

točnost, natančnost in sposobnost trgovanja, Italjani pa za slednje ter družabnost in kuharske spretnosti. Slabo ocenjujejo Slovenci avstrijsko neodkritosrčnost, škrtost in pretirano resnost ter pomanjkanje tolerance. To slednje (pri odnosu do tujcev) očitajo tudi Italjanom, ki so si nabrali negativne točke tudi zato ker so "zahrbtni", nenatančni.

Tab. 2: Tromeja - znanje jezika sosednjega(ih) naroda(ov) The knowledge of the language of the neighbour

\begin{tabular}{|c|c|c|c|c|c|c|c|c|c|}
\hline \multirow{3}{*}{ Naselje } & \multirow{3}{*}{ (št.resp.) } & \multicolumn{8}{|c|}{ Znanje tujega jezika } \\
\hline & & \multirow{2}{*}{1} & \multicolumn{3}{|c|}{ Italijanščine } & \multicolumn{4}{|c|}{ Nemščine } \\
\hline & & & 2 & $\begin{array}{r}3 \\
\%)\end{array}$ & 4 & 1 & 2 & & 4 \\
\hline Rateče & (12) & 33 & 33 & 25 & 8 & 0 & 50 & 33 & 17 \\
\hline Podkoren & (13) & 8 & 15 & 54 & 23 & 31 & 31 & 23 & 15 \\
\hline Kr. gora & (12) & 25 & 25 & 17 & 33 & 75 & 17 & 8 & 0 \\
\hline Gozd Martuljek & (12) & 0 & 25 & 0 & 75 & 17 & 33 & 33 & 17 \\
\hline Dovje & (8) & 0 & 25 & 25 & 50 & 0 & 38 & 25 & 38 \\
\hline Mojstran. & (10) & 0 & 0 & 10 & 90 & 30 & 30 & 30 & 10 \\
\hline Trenta & (12) & 25 & 33 & 17 & 25 & 8 & 25 & 25 & 42 \\
\hline Soča & (11) & 38 & 36 & 9 & 18 & 0 & 18 & 9 & 72 \\
\hline Bovec & (11) & 45 & 45 & 10 & 0 & 9 & 9 & 55 & 27 \\
\hline Čezsoča & $(15)$ & 47 & 20 & 20 & 13 & 13 & 27 & 27 & 33 \\
\hline Žaga & (11) & 18 & 55 & 27 & 0 & 0 & 10 & 18 & 72 \\
\hline DOLINA & $(67)$ & 12 & 21 & 22 & 45 & 27 & 33 & 25 & 15 \\
\hline ZG.POSOČ & (60) & 35 & 37 & 17 & 12 & 7 & 18 & 27 & 48 \\
\hline TROMEJA & (127) & 23 & 28 & 20 & 29 & 17 & 26 & 26 & 31 \\
\hline
\end{tabular}

1 = dobro, razume in govori jezik sosednjega naroda; sehr gut, versteht und spricht die Sprache

2 = srednje, se sporazumeva $v$ jeziku sosednjega naroda; gut, kann sich mit Nachbarn in deren Muttersprache verstaendigen

3 = slabo, pozna nekaj besed iz besednjaka sos. naroda; schlecht, versteht nur einige Worte, benutzt Haende

4 = ne zna, ne govori in ne razume sosednjega naroda, versteht und spricht die Sprache des Nachbars ueberhaupt nicht

Posebej izstopa razlika pri ocenjevanju med gorenjskim in primorskim delom Tromeje. V vseh kategorijah, brez izjeme, so dobili bližnji sosedje višje točke (Tab. 3). Ob seštevku enih in drugih se je pokazalo, da imamo opraviti z ostro ločnico preferenc. Gorenjci, z izjemo obeh najbolj zahodno lociranih naselij, dajajo izključno prednost Avstrijcem. Z njimi so pripravljeni trgovati, se pogovarjati in jih podpreti. Primorci so oblikovali nasproten pol. Bolj zaupajo Italjanom in so pripravljeni to svojo usmeritev še bolj vneto zagovarjati kot Gorenjci svojo. V sredo mednje gre, poleg že obeh prej omenjenih naselij v Dolini, umestiti še Trentarje (Tab. 4). 
Grenak priokus je pustilo vprašanje o tem kako menijo, da gledajo nanje sosedje. Za Avstrijce je skoraj polovica povprašanih menila, da gledajo le-ti nanje zviška, podcenjevalno (48.3\%). $V$ opravičilo Italjanom, da jim niso namenili podobno visokega odstotka (35.4\%) so menili, da so tudi oni postali $\mathrm{z}$ devalvacijo valute reveži in da, zaradi močnega tolarja, bolj prizanesljivo gledajo na vzhodne sosede. Med odgovori, ki naj bi razjasnili vzroke za negativna stališča sosedov do nas, so izstopali tisti, ki se navezujejo na pojem "Balkan" češ, "nas imajo še vedno za Jugoviče, Balkance" ali njim, torej Avstrijcem in Italjanom (kot poprej) podrejene. Le redki Italjani in Avstrijci naj bi, po izjavah Slovencev, na nas gledali prijazno, posebno zato, "ker smo reveži", "ker živimo na robu vojne", i.t.d. V navezavi na to misel mnogi ugotavljajp, da menijo Avstrijci in Italjani, da smo pametni, ker smo znali še ob pravem času reagirati in se ločiti od krvi željnih sosedov (Tab. 4).

Tab. 3a: Tromeja - vrednotenje karakternih lastnosti sosednjega(ih) naroda(ov): Italjani A valorisation of selected features of the neighbouring culture

\begin{tabular}{|c|c|c|c|c|c|c|c|c|c|c|}
\hline \multirow{4}{*}{ Naselje } & \multirow{4}{*}{ (št.resp.) } & \multicolumn{9}{|c|}{ Lastnosti sosednjega naroda } \\
\hline & & \multirow{3}{*}{1} & \multicolumn{5}{|c|}{ Italijani } & & \multirow{3}{*}{8} & \\
\hline & & & 2 & 3 & 4 & & 6 & 7 & & 9 \\
\hline & & & & & ena 1 & $5 / \mathrm{V}$ & rt $1-$ & & & \\
\hline Rateče & (12) & 2.9 & 2.8 & 3.5 & & 2.4 & & & 2.5 & 3.0 \\
\hline Podkoren & (13) & 2.4 & 2.2 & 2.9 & $4 .($ & 2.8 & 3.3 & 2.6 & 3.4 & 4.3 \\
\hline Kr. gora & (12) & 1.5 & 1.8 & 1.8 & 1.9 & 1.0 & 2.3 & 2.6 & 2.0 & 1.9 \\
\hline Gozd Martulj. & (12) & 2.1 & 1.8 & 2.3 & 3.5 & 2.2 & 3.0 & 2.4 & 2.4 & 2.0 \\
\hline Dovje & (8) & 2.0 & 1.9 & 3.6 & 3.6 & 2.6 & 4.1 & 2.6 & 2.7 & 3.8 \\
\hline Mojstran. & $(10)$ & 2.6 & 2.2 & 2.2 & 3.0 & 2.4 & 3.0 & 2.2 & 2.6 & 2.8 \\
\hline Trenta & (12) & 2.2 & 2.2 & 3.2 & 3.7 & 3.5 & 3.8 & 2.0 & 2.8 & 4.3 \\
\hline Soča & (11) & 2.5 & 2.8 & 4.2 & 4.7 & 2.3 & 3.2 & 2.5 & 3.5 & 3.5 \\
\hline Bovec & (11) & 3.8 & 4.0 & 4.4 & 4.1 & 3.7 & 4.5 & 4.2 & 4.3 & 4.2 \\
\hline Čezsoča & (15) & 2.7 & 2.9 & 4.6 & 4.3 & 3.8 & 4.5 & 3.3 & 4.2 & 4.3 \\
\hline Žaga & (11) & 4.0 & 3.5 & 4.3 & 4.3 & 3.2 & 4.5 & 3.3 & 3.8 & 3.8 \\
\hline DOLINA & (67) & 2.2 & 2.1 & 2.7 & 3.3 & 2.2 & 3.2 & 2.5 & 2.6 & 2.9 \\
\hline ZG.POSOČ. & (60) & 3.1 & 3.1 & 4.2 & 4.2 & 3.4 & 4.2 & 3.2 & 3.9 & 4.1 \\
\hline TROMEJA & (127) & 2.6 & 2.5 & 3.3 & 3.7 & 2.7 & 3.6 & 2.8 & 3.2 & 3.4 \\
\hline
\end{tabular}

$1=$ točnost/puenktlich sein 5 . toleranca / tolleranz besitzen 9 . kuhinja /gute Kueche

2 = natančnost/praeziese sein 6 . družabnost $/$ Gemuetlichkeit schaetzen

$3=$ prijaznost $/$ freundlich sein 7 . sodelovanje $/$ kooperationsbereit sein

4 = trgovska žilica / geschaeftstuechtig sein 8. veseljaštvo / froehlich sein koennen 
Sodobni pogled na prekomejno...

Tab. 3b: Tromeja - vrednotenje karakternih lastnosti sosednjega(ih) naroda(ov): Avstrijci A valorisation of selected features of the neighbouring culture

\begin{tabular}{|c|c|c|c|c|c|c|c|c|c|c|}
\hline \multirow{2}{*}{ Naselje } & \multirow[t]{2}{*}{ (št.resp.) } & \multicolumn{9}{|c|}{ Lastnosti sosednjega naroda } \\
\hline & & 1 & 2 & $3^{A}$ & $\begin{array}{c}\text { s t r } \\
4 \\
\text { ena } 1\end{array}$ & $\begin{array}{c}\mathrm{jci} \\
5 \\
5 / \mathrm{V}\end{array}$ & $\begin{array}{r}6 \\
\text { ert } 1-\end{array}$ & 7 & 8 & 9 \\
\hline \multirow{2}{*}{$\begin{array}{l}\text { Rateče } \\
\text { Podkoren }\end{array}$} & (12) & 3.6 & 4.0 & 3.8 & 3.8 & 2.6 & 3.1 & 2.8 & 2.3 & 2.8 \\
\hline & (13) & 4.0 & 4.2 & 4.5 & 4.0 & 3.2 & 2.9 & 2.4 & 2.3 & 3.2 \\
\hline Kr. gora & (12) & 2.6 & 2.3 & 2.6 & 2.4 & 2.3 & 2.9 & 3.0 & 2.1 & 2.0 \\
\hline Gozd Martulj & (12) & 4.9 & 4.2 & 3.6 & 4.3 & 2.5 & 2.8 & 2.3 & 3.2 & 2.8 \\
\hline Dovje & (8) & 4.3 & 4.0 & 4.4 & 3.7 & 3.3 & 2.7 & 2.4 & 1.7 & 2.7 \\
\hline Mojstran & (10) & 4.4 & 4.0 & 3.6 & 4.2 & 3.0 & 3.2 & 2.9 & 2.6 & 3.1 \\
\hline Trenta & (12) & 4.5 & 4.3 & 3.3 & 4.2 & 3.2 & 3.0 & 2.5 & 2.0 & 1.7 \\
\hline Soča & (11) & 2.3 & 1.8 & 2.5 & 2.5 & 2.3 & 2.5 & 2.2 & 2.2 & 1.3 \\
\hline Bovec & (11) & 3.5 & 3.7 & 2.4 & 3.3 & 2.8 & 1.5 & 1.6 & 1.5 & 1.8 \\
\hline Čezsoča & (15) & 3.8 & 3.3 & 3.8 & 4.0 & 2.8 & 2.8 & 3.3 & 3.0 & 3.3 \\
\hline Žaga & (11) & 2.7 & 2.7 & 2.7 & 2.5 & 2.2 & 2.3 & 1.7 & 2.5 & 2.2 \\
\hline DOLINA & (67) & 3.9 & 3.8 & 3.7 & 3.8 & 2.8 & 2.9 & 2.6 & 2.4 & 2.8 \\
\hline .ZG.POSOČ & $(60)$ & 3.5 & 3.3 & 3.0 & 3.4 & 2.5 & 2.4 & 2.4 & 2.3 & 2.2 \\
\hline TROMEJA & (127) & 3.7 & 3.6 & 3.4 & 3.6 & 2.7 & 2.7 & 2.5 & 2.4 & 2.5 \\
\hline
\end{tabular}

$1=$ točnost/puenktlich sein 5 . toleranca/tolleranz besitzen 9 . kuhinja/gute Kueche

$2=$ natančnost/praeziese sein 6 . družabnost/Gemuetlichkeit schaetzen

$3=$ prijaznost/freundlich sein 7 . sodelovanje/kooperationsbereit sein

$4=$ trgovska žilica/geschaeftstuechtig sein 8 . veseljaštvo/froehlich sein koennen

Planiranje komplementarnega razvoja ob Tromeji je $\mathrm{v}$ novih prilikah zastalo. V kolikor želimo zastavljene načrte o smučiščih na Peči, o plezalni in smučarski šoli v Planici, o "Vasi treh dežel", o investicijah v regionalno prometno (krožna avtobusna zveza) in turistično infrastrukturo ..... uresničiti ter dati bodočemu načrtovanju razvoja Doline in Zgornjega Posočja ustrezno mesto znotraj in zunaj Triglavskega narodnega parka, bomo morali posvetiti večjo pozornost izobrazbi, ki naj prvenstveno omogoča komuniciranje z sosedom in eliminira etnične predsodke na katerikoli strani Tromeje. Francosko-nemška nasprotja so se izgladila predvsem zaradi učenja mlade generacije $\mathrm{v}$ duhu prijateljstva. 
Tab. 4: Tromeja - vrednotenje slovenske nacije iz zornega kota sosednjega(ih) naroda(ov) kot ga občutijo Slovenci

A view of the Slovene culture by the neighbours, as felt by the Slovenians

\begin{tabular}{|c|c|c|c|c|c|c|c|c|}
\hline \multirow{2}{*}{ Naselje } & \multirow[t]{2}{*}{ (št.resp.) } & \multicolumn{7}{|c|}{$\begin{array}{l}\text { Število respondentov, ki } \\
\text { menijo, da gledajo nanje zviška }\end{array}$} \\
\hline & & $\begin{array}{r}\mathrm{Ne} \\
\text { Nein }\end{array}$ & $\begin{array}{c}\text { Italj } \\
\mathrm{Da} \\
\mathrm{Ja}\end{array}$ & $\begin{array}{l}\text { ani } \\
\text { Nevem } \\
\text { Weiss } \\
\text { nicht }\end{array}$ & $\begin{array}{r}\mathrm{Ne} \\
\text { Nein }\end{array}$ & $\begin{array}{c}\text { strijc } \\
\mathrm{Da} \\
\mathrm{Ja}\end{array}$ & $\begin{array}{l}\text { Nevem } \\
\text { Weiss } \\
\text { nicht }\end{array}$ & $?^{*}$ \\
\hline Rateče & (12) & 3 & 2 & 3 & 2 & 1 & 5 & 4 \\
\hline Podkoren & (13) & 2 & 1 & 7 & 2 & 2 & 6 & 3 \\
\hline Kr. gora & (12) & 2 & 0 & 6 & 3 & 1 & 4 & 4 \\
\hline GozdMart. & (12) & 3 & 2 & 6 & 7 & 2 & 2 & 1 \\
\hline Dovje & (8) & 2 & 0 & 5 & 4 & 0 & 3 & 1 \\
\hline Mojstran. & (10) & 4 & 0 & 5 & 1 & 4 & 4 & 1 \\
\hline Trenta & (12) & 3 & 0 & 3 & 1 & 0 & 5 & 6 \\
\hline Soča & (11) & 2 & 4 & 0 & 3 & 3 & 0 & 5 \\
\hline Bovec & (11) & 1 & 4 & 5 & 9 & 0 & 1 & 1 \\
\hline Čezsoča & (15) & 6 & 4 & 2 & 8 & 3 & 1 & 3 \\
\hline Žaga & (11) & 2 & 1 & 3 & 3 & 1 & 2 & 5 \\
\hline DOLINA & (67) & 16 & 5 & 32 & 19 & 10 & 24 & 14 \\
\hline ZG.POSOČ. & $(60)$ & 14 & 13 & 13 & 24 & 7 & 9 & 20 \\
\hline TROMEJA & (127) & 30 & 18 & 45 & 43 & 17 & 33 & 34 \\
\hline
\end{tabular}

* niso se izjasnili / wollten sich nicht aeusseren

\section{LITERATURA}

Backe, B., 1991, Das interuniversitaere Forschungsprojekt "Dreilaendereck-Grenzregion". Ein Werkstattbericht, Regional-forschung von grenzueberschreitender Bedeutung: Kaernten-Slowenien/Kroatien, AMR INFO, Vol.22/1-3, str.67-75, Wien.

Bufon, M., 1993, Meje in narodnosti: Potek ekskurzije v Italiji; Program, povzetki, vodnik; Mednarodno posvetovanje Geografija in narodnosti, str. 44 - 50, Ljubljana.

Gosar, A., 1979, Die Frequenz der grenzueberschreitenden Touristenstroeme nach Jugoslawien, bzw. Slowenien, Tourism and Borders, Frankfurter wirtschaftsgeographische und sozialgeographische Schriften 31, str. 25-30, Frankfurt/Main.

Gosar, A., 1984, Grenzueberschreitende Wanderungen zwischen Slowenien (Jugoslawien) 
und Oesterreich und ihre geographischen Auswirkungen, Oesterreich in Geschichte und Literatur mit Geographie, Vol. 28/5, str. 313-328, Wien.

Gosar, A., 1991, Ansaetze fuer eine komplementaere grenzueber-schreitende Regionalentwicklung des Dreilaenderecks (bzw. des Gail-, Save- und Kanaltales) Regionalforschung vongrenzueberschreitender Bedeutung: Kaernten-Slowenien / Kroatien, AMR INFO, Vol.22/1-3, str.61-67, Wien.

Gosar, A., 1992, The Three Border Area of Austria, Italy and Yugoslavia in Preparation for the Winter Olympics, Mountain Resort Development, str. 171-182, Burnaby B.C. Gosar, A., 1993, Nationalities of Slovenia - Changing Ethnic Structures in Central Europe, GeoJournal, Vol.30,3, Dordrecht/Boston/London.

Kunaver, J., 1989, Preobražanje goratega sveta Slovenije, Slovenija 88, Okolje in razvoj, str. 68-81, Ljubljana.

Pak, M.,(ed.), 1990, Tromeja - obmejna regija Jugoslavije, Avstrije in Italije, Das Dreilaendereck - eine Grenzregion Oesterreichs, Italiens und Jugoslawiens, Le Tre Regioni di Confine - Un Area Transconfinariatra Italia, Jugoslavia ed Austria, Dela 7, Ljubljana.

Podlipnig, K., 1991, Die Wirtschaftsbeziehungen zwischen Kaernten und Slowenien - Stand und Perspektiven, Regionalforschung von grenzueberschreitender Bedeutung: Kaernten-Slowenien / Kroatien, AMR INFO, Vol.22/1-3, str.119-127, Wien.

Steinecke, E., 1991a, Friaul - Friuli: Bevoelkerung und Ethnizitaet, Innsbrucker geographische Studien, Band 19, Innsbruck.

Steinecke, E., 1991b, Gebirgsentvoelkerung und ihr Einfluss auf die sprachliche Minderheiten in den Venezianischen Alpen, Mitteilungen der Oesterreichischen geographischen Gesellschaft, Band 133, str. 169-174, Wien.

Valussi, G., 1990, La Val Canale, un Angolo su tre Confini, Tromeja - obmejna regija Jugoslavije, Avstrije in Italije, Das Dreilaendereck - eine Grenzregion Oesterreichs, Italiens und Jugoslawiens, Le Tre Regioni di Confine - Un Area Transconfinaria tra Italia, Jugoslavia ed Austria, Dela 7, Ljubljana.

Wastl-Walter, D./Krutner, E., 1991, Die wirtschaftliche Bedeutung des Einkauftourismus aus Slowenien fuer Klagenfurt und Suedkaernten, Regionalforschung von grenzueberschreitender Bedeutung: Kaernten-Slowenien/Kroatien, AMR INFO, Vol.22/1-3, str.103-119, Wien.

Zupančič, J., 1993, Meje in narodnosti: Potek ekskurzije v Italiji; Program, povzetki, vodnik; Mednarodno posvetovanje Geografija in narodnosti; str. 44 - 50, Ljubljana. 


\title{
CONTEMPORARY STUDIES ON THE THREE-BORDER AREA OF SLOVENIA, ITALY AND AUSTRIA
}

\author{
Summary
}

Contrary to popular discussions among tourism- and regional planning experts, environmental concerns have not reached Eastern Alps yet. The Three-Border alpine area of Slovenia, Italy and Austria, including the Sava-, Soča-, Gail- and the Val Canale valleys, is keen to organize a large scale winter sport competition and change the appearance of the area completely. The international cooperation, not only in sports, could support border region economies and implement growth. Regional identity, which doesn't pay attention to national borders, political systems or economic alliances was particularly strong in times of the "cold war" in sports and ahead of the Yugoslavian devolution. At present, realistic planning, based on available resources, is in place.

The once supportive economies of the Three-Border area were dismembered after the collapse of the Austro-Hungarian monarchy in 1919. National interests of Romance Italy, German Austria and Slavic Yugoslavia have replaced empire's structures. A single state's economy was replaced by a multitude of economies among which no links were established for almost a half of a century (closed borders!). On bilateral basis and particularly within the Working Group "Alpen-Adria", established in 1978, first steps were made to overcome the situation. Between 1921 and 1991 Italians in Val Canale tripled the ethnic size, forced migrations of East-European Germans have decreased the size of Slovenes to a marginal minority in the Gail Valley, and the well-off economies of Slovenia, including tourism, have attracted migrants from the Balkan peninsula to the region, making the area a multicultural one. The caecum of former Yugoslavia, the Upper Soča Valley experienced intensive decline in residency. In their development plans the Italian side counted on trade and traffic, the Slovenian on tourism and steel production, the Austrian on industry, traffic and tourism. With the exception of a few cooperations in sports, not much has been done to tie neighboring economies.

Experts of universities Ljubljana, Klagenfurt, Udine and Trieste have agreed to study existing potentials and elaborate on future moves in regard of the willingness of local governments to cooperate. The following are steps which could be made to change the image and increase touristic potentials:

* the development of a regional infrastructure, disregarding transnational connections;

* the increase of potentials in tourism with an uplifting of existing conditions and a venturesome creation of new touristic attractions;

* the enlargement of potentials in traditional handcraft-manship and cooperation in its production;

* the development of a marketing and executive strategy, implementing interest among investors, visitors and managers. 
Since a unified image must be established the marketing top image proposal of " 4 X 3 " or "3 Countries, 3 Cultures, 3 Languages and 3 Nations" seems appropriate. One could elaborate on the marketing slogan calling for "The Heart of the Alpen-Adria Region". The leading attractions of the area would be natural and man made. Among first the geomorphologic, biologic and cultural uniqueness of the Julian Alps must put on first place. Using rushing streams and mountains must be made in regard of the principles of sustainability. Man made attractions exist in form of several skiing grounds (lately many were constructed in the Tarvisio area), the ski-jumping Mecca of Europe - Planica, the underground world of the mining area of Bleiburg, several shopping attractions (duty free shops) and gambling places. Planning proposals are for the construction of a multicultural village with several gourmet offerings and handicraft productions, for the increase of skiing grounds on the Austrian side of the Three-Border Crossings Mt./Peč-Fuorno-Ofen/ with a linkage to the now empty traffic space (Karawanken-Tunnel, 1992) at the Wurzen/Koren Pass, for several information centers in relation to the Julian Alps, the Triglav National Park and the ThreeBorder area and many more. 